\title{
Testimony for veterinary apitherapy
}

\section{Background}

Nowadays by the indiscriminate use of antibiotics, multi-drug resistant pathogens (MDR) developed and spread, so searching for effective natural antimicrobials is of global concern. Apitherapy possessing various therapeutic activities (antimicrobial, ${ }^{1,2}$ anti-inflammatory, ${ }^{3-5}$ antioxidant, ${ }^{6-9}$ antiproliferative, ${ }^{10}$ immunomodulator ${ }^{11}$ ameloirative ${ }^{12,13}$ or wound healing factor ${ }^{14,15}$ proved to be a suitable tool to get the target since it is very safe, highly effective, easily applicable and extremely economic. The subject is of interesting concept for the apitherapy research team affiliating to Animal Health Research Institute, assiut and Faculty of Veterinary Medicine, Assiut University, Egypt. The team produced many research works (no 12) which were tabulated in tables 1(in vitro antimicrobial activity), 2(antioxidant, immunomodulative and toxicity ameliorative factors) and 3(applied honey apitherapy in lactating dairy cows) dealt with different veterinary apitherapeutic applications of different apiproducts; honey, propolis and bee venom.

Keywords: apitherapy, fennel, antimicrobial, antioxidant, immune boosting, wound healing, methoxychlor toxicity
Volume 12 Issue I - 2019

\section{Abdul-Hafeez MM \\ Animal Health Research Institute, Egypt}

Correspondence: Abdul-Hafeez MM,Animal Health Research Institute,Assiut Lab, Egypt, Email mohhafeez5555@gmail.com

Received: November 20, 2018 | Published: January 17, 2019

\section{Introduction}

Apitherapeutic management is reborn in the modern medicine, established documentary and be advised by physicians to wide variety of patients complaining different health problems. The concept of veterinary apitherapy must be of great concern as it highly safe of animal products extremely effective and greatly economic. As mentioned above, apitherapy has wide spectrum therapeutic activities with variable varieties of mechanism of action, of among them, our referred research works dealt with

Table I In vitro studies of honey antimicrobial activity against clinical different MDR bacterial spP

\begin{tabular}{|c|c|c|c|c|c|c|}
\hline Bact Spp. & Source & Honey & Method & MIC & MBC & Reference \\
\hline S. aureus & & & & $10 \%$ & & \\
\hline \multicolumn{7}{|l|}{ S. intermedius } \\
\hline S. epidermedis & Bovine purulent endometritis & cotton & & $20 \%$ & UD & Abdul-Hafeez et al. ${ }^{44}$ \\
\hline \multirow{2}{*}{\multicolumn{7}{|c|}{$\begin{array}{l}\text { S. sapropnyticus } \\
\text { Strept. agalactiae }\end{array}$}} \\
\hline & & & & & & \\
\hline S. aureus & & & & $12.5 \%$ & $25 \%$ & \\
\hline \multicolumn{7}{|l|}{ Ps. auroginosa } \\
\hline Proteus spp. & Bovine subclinical mastitis & Fennel* & & $25 \%$ & UD & Ali et al. ${ }^{18}$ \\
\hline KI. pneumoniae & & & Broth & & & \\
\hline S. aureus & & & dilution in & $8 \%$ & $15 \%$ & \\
\hline S. intermedius & & Fennel honey & & $7.5 \%$ & $13 \%$ & \\
\hline S. epidermedis & Bovine subclinical mastitis & with $10 \%$ propolis & & $15 \%$ & $28 \%$ & Aamer et al. ${ }^{19}$ \\
\hline \multirow[t]{9}{*}{ S. saprophyticus } & & extract** & & $27 \%$ & $42 \%$ & \\
\hline & Dairy food & & & $7 \%$ & & \\
\hline & Meat & & & $10.6 \%$ & & \\
\hline & Throat (dairy food workers) & Fennel honey & & $9.3 \%$ & & \\
\hline & Fingernail (dairy food workers) & & & $8.2 \%$ & & \\
\hline & Dairy food & & & $14 \%$ & & \\
\hline & Meat & & & $15 \%$ & & \\
\hline & Throat (dairy food workers) & EEP & & $12 \%$ & & \\
\hline & Fingernail (dairy food workers) & & & $16 \%$ & & \\
\hline \multirow[t]{4}{*}{ MRSA } & Dairy food & & Agar & $7.1 \%$ & & Hamouda et al. ${ }^{2}$ \\
\hline & Meat & $5 \%$ Fennel honey**** & dilution & $8 \%$ & & \\
\hline & Throat (dairy food workers) & $\begin{array}{l}\text { with } \\
5 \% \text { EEP }\end{array}$ & & $8.2 \%$ & & \\
\hline & Fingernail (dairy food workers) & & & $7.7 \%$ & & \\
\hline
\end{tabular}

I. All isolated bacterial species were tested for antibiotic sensitivity (disc diffusion method) showing to be as MDR strains, and then be tested against honey.

2. *Fennel honey showed the least MIC than that of Prickly, Sesame and cotton honey batches.

3. **Fennel with $10 \%$ EEP showed the least MIC than two different pure fennel, two different trefoil, marjoram. And cotton honey batches.

4. ***Fennel with $5 \%$ EEP (synergy) showed the least MIC than pure Fennel honey or pure EEP.

5. UD: undone. 
Table 2 Apitherapy in normal healthy animals as antioxidant, immunomodulative and toxicity ameliorative factors

\begin{tabular}{|c|c|c|c|c|c|}
\hline Studied parameter & Animal & Apiproduct & Mode of application & Conclusions & Reference \\
\hline \multirow[t]{2}{*}{$\begin{array}{l}\text { Antioxidant activity } \\
\text { and immunomodulation }\end{array}$} & Goats & fennel honey & $\begin{array}{l}\text { Rapidly intravenously } \\
\text { infused } 20 \% \text { honey } \\
\text { solution ( } 70-80 \text { drops/ } \\
\text { min) in normal saline } \\
\text { solution }\end{array}$ & $\begin{array}{l}\text { In } 75 \% \text { of infused goats: } \uparrow \text { the } \\
\text { activity of antioxidants (GPX } \\
\text { \& SOD) and } \downarrow \text { free radicals } \\
\text { metabolites, improving haemo- } \\
\text { ideces ( } \uparrow W B C s, \uparrow l y m p h o c y t e s, \\
\uparrow \text { monocytes and } \uparrow \text { serum } \\
\text { globulins). While the rest } 25 \% \\
\text { had anaphylactic shock and died. }\end{array}$ & Abdel-Mooty et al. ${ }^{7}$ \\
\hline & & fennel honey & $\begin{array}{l}\text { Oral \& intraperitoneal } \\
10 \% \text { honey solution } \\
\text { administration for } 60 \text { days }\end{array}$ & & \\
\hline \multirow[t]{2}{*}{$\begin{array}{l}\text { Boosting immunity prior } \\
\text { experimental induced } \\
\text { infection }\end{array}$} & $\begin{array}{l}\text { Sprague } \\
\text { Dawley } \\
\text { rats }\end{array}$ & EEP & $\begin{array}{l}\text { Oral \& intraperitoneal } \\
\text { administration of } \\
\text { aqueous(AEP) \& ethanolic } \\
\text { extract(EEP) for } 60 \text { days }\end{array}$ & $\begin{array}{l}\text { All were immunized where oral } \\
\text { honey administration showed } \\
\text { the highest immunization rate }\end{array}$ & Sayed et al. ${ }^{61}$ \\
\hline & & $\begin{array}{l}\text { Bee venom } \\
\text { (bee sting) }\end{array}$ & $\begin{array}{l}\text { Single bee sting for } 5 \\
\text { successive times }\end{array}$ & & \\
\hline \multirow[t]{2}{*}{$\begin{array}{l}\text { Ameliorative effects } \\
\text { against } M X C \text { toxicity }\end{array}$} & $\begin{array}{l}\text { Sprague } \\
\text { Dawley }\end{array}$ & EEP & $\begin{array}{l}\text { Orally EEP }(200 \mathrm{mg} / \mathrm{L} \text {, } \\
\text { drinking water }) \text { for } \mathrm{I} 2 \\
\text { months }\end{array}$ & $\begin{array}{l}\text { propolis protcted } \mathrm{MXC} \text {-induced } \\
\text { hepato renal toxicity }\end{array}$ & Neveen El Nesr et al. ${ }^{76}$ \\
\hline & rats & EEP & $\begin{array}{l}\text { Orally EEP }(200 \mathrm{mg} / \mathrm{L} \text {, } \\
\text { drinking water) for } 10 \\
\text { months }\end{array}$ & $\begin{array}{l}\text { propolis decreased MXC- } \\
\text { induced ovarian toxicity }\end{array}$ & $\begin{array}{l}\text { Eman El Sharkawy et } \\
\text { al. }^{.7}\end{array}$ \\
\hline
\end{tabular}

Table 3 Application of honey apitherapy in lactating dairy cows

\begin{tabular}{|c|c|c|c|}
\hline Bovine affection & Mode of application & Conclusions & Reference \\
\hline $\begin{array}{l}\text { Purulent endometritis } \\
\text { (with repeat breeder) }\end{array}$ & $\mathrm{I} / \mathrm{U}$ infusion $00 \mathrm{ml}$ honey day by day three successive doses & $\begin{array}{l}75 \% \text { of treated cows got } \\
\text { conception }\end{array}$ & Abdul-Hafeez et al. ${ }^{44}$ \\
\hline \multirow{2}{*}{ Subclinical mastitis } & $\begin{array}{l}\mathrm{l} / \mathrm{Mm} \text { infusion of } 10 \mathrm{ml} \text { of } 50 \% \text { fennel honey day by day three } \\
\text { successive doses }\end{array}$ & $\begin{array}{l}\text { Milk yield increased } \\
\text { significantly }\end{array}$ & Abdul-Hafeez et al. ${ }^{92}$ \\
\hline & $\begin{array}{l}\mathrm{I} / \mathrm{Mm} \text { infusion of } 10 \mathrm{ml} 10 \% \text { fennel honey day by day three } \\
\text { successive doses guarded by antihistaminic administration }\end{array}$ & $\begin{array}{l}\text { Milk yield increased } \\
\text { significantly }\end{array}$ & Nahed Wahba et al. ${ }^{93}$ \\
\hline $\begin{array}{l}\text { Surgical claw } \\
\text { affections(digital } \\
\text { dermatitis and inter digital } \\
\text { necrobacillosis) }\end{array}$ & $\begin{array}{l}\text { Pure honey* bandage for } 5 \text { consecutive days; } 2 \text { days without } \\
\text { management; then once daily for other } 3 \text { days only up to } 14 \text { days. }\end{array}$ & $\begin{array}{l}\text { Complete healing repair and } \\
\text { hair developed by } 14 \text { days }\end{array}$ & Ali et al. ${ }^{94}$ \\
\hline
\end{tabular}

$\mathrm{I} / \mathrm{U}$; intrauterine, I/Mm; intramammary

Honey*: showed healing manifestations earlier than other medical herbal (T. vulgaris, O. vulgare and M.chamomilla) lotion and ointments.

\section{Antimicrobial activity (In vitro assay)}

Antibiotic resistance of bacteria is on the rise, thus the discovery of alternative therapeutic agents is urgently needed ${ }^{2}$. Since the antimicrobial honey activity proved to have wide varied potencies depending on botanical, geographical and seasonal conditions ${ }^{2,16}$ leading to differences in antimicrobial potency more than 100-fold in-between different honeys, ${ }^{2,17}$ the in vitro assessment before any honey therapeutic use is required. Fennel honey among Egyptian honey batches has highly antimicrobial activity compared with prickly, sesame and cotton honey ${ }^{18}$ or trefoil, marjoram and cotton honey ${ }^{19}$ showing synergistic action when adding ethanolic extract of propolis (EEP) $)^{14,19}$ even only 5\% of both. ${ }^{2}$ Honey EEP synergy is proved against different Staph species ${ }^{19,20}$ or even stubborn methicillin resistant $(\mathrm{MRSA})^{2}$ strains biofilm producing with much antibacterial resistance either from bovine or human sources ${ }^{2}$. The antimicrobial activity of crude unprocessed honey is maximized when be diluted and diminished when be autoclaved or heated, ${ }^{21}$ where this potency is highly complex due to the involvement and interaction of multiple compounds in honey. ${ }^{22}$ Egyptian fennel honey inhibits MRSA at $7 \%{ }^{2}$ and Gram's negative (proteus, pseudomonas, klebsiella) at $25 \% .{ }^{18}$ Despite, EEP has promising activity against Klebsiella pneumonia, ${ }^{23}$ Strept mutans ${ }^{24}$ E. coli $i^{21}$ particularly in high concentration ${ }^{24}$ but much lower antimicrobial potency than honey. ${ }^{2}$ Bee venom apitherapeutic application (Bee sting) might provide antimicrobial activity.,25

The in vitro honey antibacterial activities depend on physicochemical properties (osmotic pressure, low $\mathrm{pH}$ of 3 to 4.5 and non-peroxide factors as polyphenols, ${ }^{1,26}$ phenolic acids as caffiec and flavonoids mainly chrysin) ${ }^{8,27}$ as well as peroxide effects due to 
$\mathrm{H}_{2} \mathrm{O}_{2}$ level in honey which is involved in oxidative damage causing bacterial growth inhibition by DNA degradation and modulated by other honey components. ${ }^{26}$ Although $\mathrm{H}_{2} \mathrm{O}_{2}$ is an important factor in the bacterial growth inhibition, polyphenolic compounds and their interaction with $\mathrm{H}_{2} \mathrm{O}_{2}$ are the key factors responsible for honey high antibacterial activity. ${ }^{28}$ Other micro components honey glycoprotein fractions as antimicrobial peptide bee defensin- $1^{11,22}$ exhibited strong growth inhibition by binding and agglutination of bacterial cells or membrane permeabilization of bacterial cells. ${ }^{29,30}$ Moreover, the presence of methylglyoxal(MGX) exhibited in manuka honey may modify some honey proteinaceous compounds and therefore affect the glucosidase activity ${ }^{31}$ sharing in antimicrobial action. Staph aureus is a pathogen highly sensitive to the antibacterial action of honey $y^{32}$ even when be MRSA $^{33}$ producing biofilm ${ }^{2}$ with additional different antibacterial mechanisms; inhibition of cell division, collapsing microbial cytoplasm cell membranes and cell walls, inhibition of bacterial motility, enzyme inactivation, bacteriolysis, and protein synthesis inhibition. ${ }^{34}$ Inhibition of biofilm formation by reducing the expression of 2-fibronectin binding proteins by honey $\mathrm{MGX}^{35}$ which is abundant component in manuka honey (the highest antimicrobial antioxidant). ${ }^{36}$

Bioactivities of EEP where the major constituents exhibited polyphenols, aromatic acids, terpenes and flavonoids ${ }^{23}$ are not directly related to its concentration, but a synergistic activity ${ }^{37}$ and interaction between these various active ingredients is believed to be a main factor in achieving the complex antimicrobial activity of propolis. ${ }^{23,38}$ Other microbioactive components; artepillin $\mathrm{C}^{39}$ and the flavonoid formononetin, ${ }^{40}$ while polyphenols interacts with many microbial proteins by forming hydrogen and ionic bonds, thus altering their three-dimensional (3D) structure of a protein and as a consequence their functionality. ${ }^{23}$ Bee venom has antimicrobial activity where melittin (cationic peptides - AMPs), the major active peptide of bee venom $^{4,25,41}$ has antimicrobial activity affecting bacterial cell wall (outer membrane proteins and lipopolysaccharides) ${ }^{25,42}$ and colistin rather than its antibiofilm activity. ${ }^{43}$

\section{Antioxidant activity}

The imbalance between oxidative stress and antioxidant scavengers leads to damage of important biomolecules resulting in malonaldehyde (MDA) production ${ }^{45}$ and the body has a defense mechanism against its harmful effects through neutralizing the free radicals by means of either endogenous enzymatic glutathione peroxidase (GPX) and superoxide dismutase (SOD) $)^{46}$ or non-enzymatic e.g. catalase, alkaloids, ascorbate, ${ }^{47}$ flavonoids ${ }^{8,48}$ selenium, ${ }^{46}$ vit $\mathrm{C}$ and vit $\mathrm{E} .{ }^{49}$ Honey antioxidant activity exhibited by different bioactive micro components ${ }^{50}$ such as flavonoids, ${ }^{8,9}$ phenolic compounds, ${ }^{51}$ chrysin $^{52}$ and amino acids ${ }^{53}$ but the main antioxidants are considered to be the polyphenols. ${ }^{54}$ Different antinociceptive effects of different fractions from Chinese EEP mainly chrysin, ${ }^{55}$ but honey ${ }^{6}$ or propolis ${ }^{55}$ chrysin as a polyphenolic compound or galanin ${ }^{56}$ - which is an abundant component in honey - has anti-inflammatory ${ }^{3}$ and antioxidant properties ${ }^{57}$ enhancing protein stability, ${ }^{52,58}$ solid lipid nanoparticle (SLN) synthesis avoiding proteolytic degradation ${ }^{52}$ resulting antiploliferating ${ }^{6,59}$ action. This activity is achieved on honey $\operatorname{oral}^{47,60}$ or intravenous $(\mathrm{I} / \mathrm{V})^{7,10}$ administration as increase GPX \& SOD and decrease the free radical metabolites malonaldehyde (MDA) due to inhibition of the pro-inflammatory cytokines(TNF- $\alpha$, IL- $1 \beta$ and IL-6. ${ }^{60}$ Although I/V honey apitherapy proved to acquire all targeted advantages, it is not advisable avoiding risky factors ${ }^{7}$ since daily oral administration gives all positive results ${ }^{61,62}$ comparing with intra- peritoneal route where regular consumption of honey is appraised. ${ }^{61}$

\section{Boosting immunity}

There is an important correlation between high antioxidant and antimicrobial activity, ${ }^{11}$ moreover, the antioxidant components present in honey ${ }^{61-63}$ and $\mathrm{EEP}^{61,64}$ play a great role in their immunomodulation properties. So, the above mentioned bioactive components at least have all antimicrobial, antioxidant and immunological boosting factors. Honey increases $\mathrm{T}$ and B lymphocytes ${ }^{62,65,66}$ as a result of its protection of lymphocyte DNA from oxidative damage,${ }^{67}$ while manuka honey protect DNA of not only lymphocytes but also whole blood cells from oxidative damage. ${ }^{68}$ It is interesting that muscular exercise with honey oral supplementation reveals an increase in $\mathrm{T}$ lymphocyte function. ${ }^{69}$ Honey and EEP increase other blood cellular immunological elements; neutrophils ${ }^{62}$ and monocytes ${ }^{7,61,62}$ rather than serum globulin..$^{61,62}$ Moreover, apitherapeutic administration of honey ${ }^{70}$ and EEP ${ }^{64}$ activate lymphocytic function resulting in proliferation of lymphatic follicles. ${ }^{61}$ The immune system response to different stimuli depends on the secretion of different metabolites from macrophages ${ }^{4}$ and its phagocytosis might be activated with honey ${ }^{71}$ or $\mathrm{EEP}^{72,73}$ adminstration. Not only honey and propolis apitherapy improves the immune status, but also bee venom boost cellular immunity ${ }^{61}$ but less activity and honey bee pollen significantly increases the globulins level and phagocytic activity rather than neutrophils, monocytes and lymphocytes percentages. ${ }^{61,74}$ Bee venom melittin enhances the release of tumour necrosis factor- $\alpha$ (TNF- $\alpha$ ), Interleukin (IL- $1 \beta$, IL-6, and IL-10) cytokines ${ }^{4}$ from macrophages affecting the immune status positively.

\section{Amelioration effect of EEP against induced Methoxychlor (MXC) toxicity}

Although MXC (organochlorine pesticide) is banned by 2004 since failure of registration with the Environmental Protection Agency,${ }^{75}$ it is used and presented residues contaminating lakes ${ }^{12}$ or river fish, ${ }^{13}$ then animal foodstuffs. Its toxicity affects liver, ${ }^{76}$ testis, ovary, ${ }^{77}$ kidneys ${ }^{76}$ spleen, blood vessels, pituitary, adrenals and mammary glands. ${ }^{78}$ Additionally to the above bioactive properties of EEP, it is proved that having protection properties (amelioration) against MXC, ${ }^{79}$ methotrexate, ${ }^{80}$ benzopyrene ${ }^{81}$ or chlorpyrifos ${ }^{79,82}$ induced toxicity. Due to EEP immunomodulation potency by different mechanisms of micro-components (mainly flavonoids and phenolic acids), its antioxidative and anti-inflammatory ${ }^{5}$ properties resulted in such different amelioration effects and chrysin ${ }^{83}$ which inhibits induced kidney fibrosis. ${ }^{84}$ Moreover, lactating animals excrete MXC in milk ${ }^{85}$ with potential human health hazard. Subsequently, animals contract MXC toxicity result several toxicological implications as ovarian toxicity, ${ }^{77}$ where it causes impairment of ovarian follicular development and other ovarian function ${ }^{77,86}$ leading to reproductive tract malformations in the male offspring. ${ }^{87} \mathrm{MXC}$ hepto-toxicity results in significant reduction in total serum protein rather than marked elevation in hepatic marker enzymes(ALT, AST \& ALP) ${ }^{76}$ as well as changes in inter and intra cellular signaling. ${ }^{88}$ Histopathologically, there is changes in hepatocyte ${ }^{76,89}$ owing to induction changes in mRNA abundance of genes in the liver and testes,$^{90}$ where alterations involved in regulations of gene expression, tissue development, function and homeostasis, could also contribute to transgenerational epigenetic effects of endocrine disruptors. ${ }^{88}$ MXC affect kidneys causing toxic nephrosis ${ }^{76}$ and dysfunction through inhibition of renal tubular cell viability and induction of cell apoptosis via mitochondrial pathways. $^{91}$ 


\section{Honey apitherapy in lactating dairy cows}

Among different lactating Holstein dairy farms, four papers of the referred works ${ }^{44,92-94}$ applied honey apitheray were dealt with three dairy farm problems:

\section{Bovine endometritis}

Well managed and profitable dairy farming requires animal with good reproductive performance, ${ }^{95}$ but uterine postpartum infection with MDR pathogens which is so common threaten fertility ${ }^{96}$ causing major cause of economic loss. ${ }^{97}$ Bovine endometritis and prolonged luteal phase leading to repeat breeder (infertility complain) is significantly increased in cows with persistent infections. ${ }^{96}$ Alternative intrauterine $(\mathrm{I} / \mathrm{U})$ infusion was widely documented and tried; with own affected cow hyper immune serum, ${ }^{98}$ polymorph nuclear leucocytes, exotoxine of $E$. coli lipopolysaccharides, ${ }^{99}$ multiherbal extract ${ }^{100}$ chitosan, ${ }^{101}$ low dilutions of $\mathrm{H}_{2} \mathrm{O}_{2}{ }^{102}$ silver nanoparticles, ${ }^{103}$ Momordica charantia ${ }^{104}$ garlic, neem, ashwagandha, and turmeric ${ }^{105}$ or tulsi and giloy ${ }^{106}$ herbal EOs. Even lactic acid probiotic Pediococcus acidilactici and Lactobacillus reuteri ${ }^{107}$ therapy was tried concluded that treatment remains to be confirmed ${ }^{102}$ as it may increase the pregnancy rate in cows. ${ }^{104}$

Bovine honey $\mathrm{I} / \mathrm{U}$ infusion have wonderful results ${ }^{44}$ since the study conducted 24 lactating cows suffering from exudative purulent endometritis with repeat breeder complain. Despite the treatment success is judged by total conception rate not only clearance of clinical signs, it was $75 \%$ (83.8 \% in cows did not accept any antibiotics \& 70 $\%$ in cows previously antibiotic treated) just post three I/U infusions of $100 \mathrm{ml}$ pure undiluted honey day by day. In mare indometritis, MDR infection appear to be more difficult since it is commonly associated with biofilm, ${ }^{108}$ so biofilm was targeted alternatively in vitro ${ }^{109}$ and in vivo with $\mathrm{N}$-acetylcysteine, $\mathrm{H}_{2} \mathrm{O}_{2}$, ozone and hypochlorous acid giving no reducing in biofilm. ${ }^{108}$ Authors recommended to use these non-antibiotics combined with antibiotic infusion where must be administered with separate syringes. ${ }^{108}$ By $70 \%$ honey I/U infusion in mares, ${ }^{110}$ positive results to both targets (antimicrobial and antibiofilm- as mentioned above) against endometritis pathogens but not as in bovine, where treatment success is judged by endometrium ultrasound and cytological examinations showing clinically clearance of endometritis, but fertility was not improved.

\section{Bovine subclinical mastitis}

Mastitis imposes considerable economic losses on the dairy industry all over the world, ${ }^{111}$ where it is one of the most vital noteworthy monetary risks to dairy ranchers and affects reproductive performance in dairy cattle. ${ }^{112}$ The overwhelming usage of antibiotics and prolonged infection treatment has led to emergence of MDR pathogens. ${ }^{103}$ The emergence of antibiotic resistant microorganisms is a great public health concern and has triggered an urgent need to develop alternative antibiotics. ${ }^{113}$ Based on the antibacterial properties of agents from plants, the antimicrobial action of essential oils (EOs) of medicinal plants and its feasibility to be intramammary infused it is recommended, ${ }^{114}$ but as the mammary gland is very susceptible tissue to irritation, any intramammary infusions should be non-irritating. ${ }^{115}$ Following the in vitro testing, clinical trials intramammary infusion $(\mathrm{I} / \mathrm{Mm})$ of any alternative medicinal product must be warranted to determine safety and possible withdrawal time in milk before its recommendation for use. ${ }^{116}$ The in vitro assessment of EOs; Origanum vulgare ${ }^{41}$, Thymus vulgaris and Lavandula angustifolia ${ }^{117}$, fruit guttiferone-A and 7 -epiclusianone, ${ }^{118}$ onion and black cumin ${ }^{119}$ or chitosan hydrogel ${ }^{120}$ against bovine mastitis pathogens and Salvia officinalis ${ }^{116}$ against ewe subclinical mastitis pathogens was documented. EOs I/Mm application ${ }^{116,117}$ concluded variable results away from its in vitro assessment as external massage with EO ointment had activity more than that of $\mathrm{I} / \mathrm{Mm}^{117}$ or I/Mm had significant results when be combined with antibiotics ${ }^{116}$ even chitosan hydrogel is recommended only for uninfected cows as it is not a complete replacement for antibiotic dry cow therapy. ${ }^{120}$ Despite of the positive in vitro antimicrobial potency of probiotic lactic acid bacteria due to produced bacteriocin and elicit substantial innate immunity ${ }^{121}$ the I/ $\mathrm{Mm}$ infusion of Lactobacillus lactis ${ }^{121-123}$, Weissella confuse ${ }^{124,125}$ or Lactobacillus acidophilus ${ }^{126}$ concluded no increase in intramammary cure rate ${ }^{126}$ where $S$. aureus infections did not improve, and coagulase negative staphylococcal infections tended to relapse ${ }^{123}$ with abnormal milk secretions and udder inflammation. Thus its I/Mm should not be adopted, ${ }^{124}$ but $\mathrm{I} / \mathrm{Mm}$ of $10 \%$ solution of thymus and lavender $\mathrm{EOs}^{117}$ showed synergistic action which the only study recommended EOs I/ Mm infusion.

Otherwise, the in vitro testing of honey against pathogens of bovine ${ }^{2,18,19}$ and ovine mastitis ${ }^{119,127,128}$ encouraged its I/Mm infusion where by $20 \%$ fennel honey followed by $30 \%$ then $40 \%$ finally $50 \%$ (the in vitro MIC) for three successive doses ${ }^{92}$ concluded decline in total bacterial count (TBC) and highly significant increase in milk yield. But regardless to the in vitro MIC concerning boosting immunity, ${ }^{61}$ only $10 \%$ fennel honey infusion day by day for three doses guarded by antihistaminic drug significantly decreases milk TBC, increase milk yield and improves blood immunological parameters ${ }^{93}$ Subsequently, $\mathrm{I} / \mathrm{Mm}$ honey infusion is the only successful trend among alternative medicinal approach with unique drawback since extreme CMT positive results ${ }^{92,93}$ owing to the highly increased lymphocytes and total leucocytes post honey administration. ${ }^{61,62,65,66,74}$ Moreover, milk cytology could be used instead of CMT during and after treatment with honey ${ }^{93}$ Beyond mastitis negative impact on milk yield and milk components, it has a detrimental effect on reproductive performance in dairy cows ${ }^{112,129}$ rather than the mastitis following exudative metritis resulting in mastitis ascending infection.

\section{Bovine claw affections}

Topical honey application has a beneficial effect on the healing of cutaneous wounds, ${ }^{130}$ ulcers ${ }^{131}$ or infected chronic wounds showing synergism with Nigilla sativa EO. ${ }^{132}$ There is good evidence for honey also having bioactivities that stimulate the immune response promoting tissue growth and wound repair, moreover suppress inflammation. ${ }^{133}$

Twenty lactating cows suffering from claw lesions either digital dermatitis or interdigital necrobacillosis (infected wound in highly infected media) showing sever lameness were divided to equal four groups of five cows of each. Three groups were treated with medicinal plant extract of Thymus vulgaris, Matricaria chamomilla and Origanum vulgare (as lotion and ointment) with the obtained in vitro MIC value against the isolated bacteria. The rest group was dressed only with undiluted honey as honey used in wound care can withstand dilution with substantial amounts of wound exudate maintaining enough activity to inhibit the growth of bacteria ${ }^{133}$ accelerating healing process..$^{15}$ All groups had different degrees of cure post 30 days but honey group was by 14 days with complete healing ${ }^{95}$ concluded that honey is the most effective valuable economic alternative tool than herbal EOs for its healing superiority and application feasibility. 


\section{Conclusion}

Basing on the former justifications of the wide spectrum antimicrobial efficacy and promoting wound healing as well as tissue growth, honey apitherapy is advisable to be used:

i. Undiluted in cases of direct exposure with the pathogen even MDR either septic wounds \& purulent metritis or food additive as a preservative especially those of dairy sources acceptable to be sweetened.

ii. In cases of boosting immunity of healthy non affected animals or subclinical mastitis, $10 \%$ honey solution would be enough fully effective.

\section{Acknowledgment}

None.

\section{Conflicts of interests}

The authors declare that there is no conflict of interests regarding the publication of this article.

\section{References}

1. Airen B, Sarkar PA, Tomar U, et al. Antibacterial effect of propolis derived from tribal region on Streptococcus mutans and Lactobacillus acidophilus: An in vitro study. J Indian Soc Pedod Prev Dent. 2018;36(1):48-52.

2. Hamouda SM, Abd El Rahman MF, Abdul-Hafeez MM, et al. Egyptian fennel honey and/or propolis against MRSA harboring both mecA \& icaA genes. Int J Complement Alt Med. 2018;11(3):180-185.

3. Hwang SH, Kim HY, Zuo G, et al. Anti-glycation, Carbonyl Trapping and Anti-inflammatory Activities of Chrysin Derivatives. Molecules. 2018;23(7). pii: E1752.

4. Alqarni AM, Ferro VA, Parkinson JA, et al. Effect of Melittin on Metabolomic Profile and Cytokine Production in PMA-Differentiated THP-1 Cells. Vaccines (Basel). 2018;6(4).pii: E72.

5. Kitamura H, Saito N, Fujimoto J, et al. Brazilian propolis ethanol extract and its component kaempferol induce myeloid-derived suppressor cells from macrophages of mice in vivo and in vitro. BMC Complement Altern Med. 2018;18(1):138.

6. Abel SDA, Dadhwal S, Gamble AB, et al. Honey reduces the metastatic characteristics of prostate cancer cell lines by promoting a loss of adhesion. Peer J. 2018; 6:e5115.

7. Abd-El Mooty M, Neveen A EL Nisr, Nahed M Wahba, et al. Influence of intravenous Egyptian fennel honey infusion on the antioxidant activities and some haemo-indices in healthy goats. Int J Complement Alt Med. 2018;11(5):281-286

8. Cianciosi D, Forbes-Hernández TY, Afrin S, et al. Phenolic Compounds in Honey and Their Associated Health Benefits: A Review. Molecules. 2018;23(9): pii: E2322.

9. Frandsen JR, Narayanasamy P. Neuroprotection through flavonoid: Enhancement of the glyoxalase pathway. Redox Biol. 2018;14:465-473.

10. Fernandez-Cabezudo MJ, El-Kharrag R, Torab F, et al. Intravenous administration of manuka honey inhibits tumor growth and improves host survival when used in combination with chemotherapy in a melanoma mouse model. PLoS One. 2013;8(2):e55993.

11. Grecka K, Kuś PM, Worobo RW, et al. Study of the Anti-Staphylococcal Potential of Honeys Produced in Northern Poland. Molecules. 2018;23(2). pii: E260
12. Abbasi Y, Mannaerts CM. Evaluating organochlorine pesticide residues in the aquatic environment of the Lake Naivasha River basin using passive sampling techniques. Environ Monit Assess. 2018;190(6):349.

13. Unyimadu JP, Osibanjo O, Babayemi JO, et al. Levels of Organochlorine Pesticides in Brackish Water Fish from Niger River, Nigeria. J Environ Public Health. 2018;2018:2658306.

14. Takzaree N, Hadjiakhondi A, Hassanzadeh G, et al. Synergistic Effect of Honey and Propolis on Cutaneous Wound Healing in Rats. Acta Med Iran. 2016;54(4):233-239.

15. Takzaree N, Hassanzadeh G, Rouini MR, et al. Evaluation of the Effects of Local Application of Thyme Honey in Open Cutaneous Wound Healing. Iran J Public Health. 2017;46(4):545-551.

16. Gül A1, Pehlivan T. Antioxidant activities of some monofloral honey types produced across Turkey. Saudi J Biol Sci. 2018;25(6):1056-1065.

17. Molan PC. Cooper RA. Honey and sugar as a dressing for wounds and ulcers. Trop Doct. 2000;30(4):249-250.

18. Ali MM, Nahed M, Wahba. Antibacterial activity of honey for treatment of subclinical bovine Mastitis: 1-In vitro study of bacterial inhibits and chemical bioassay of some different honeys. 8th Sci Cong. Egyptian society for cattle diseases Assiut Egypt. 2005. p. 139-146.

19. Aamer AA, Abdul-Hafeez MM, Sayed SM, et al. Minimum Inhibitory and Bactericidal Concentrations (MIC \& MBC) of Honey and Bee Propolis against Multidrug Resistant (MDR) Staphylococcus Sp. Isolated from Bovine Clinical Mastitis. Global Journal of Science Frontier Research: D: Agriculture and Veterinary. 2015;15(2):21-28.

20. Takzaree N, Hadjiakhondi A, Hassanzadeh G, et al. Synergistic effect of honey and propolis on cutaneous wound healing in rats. Acta Med Iran 2015;54(4):233-339.

21. Elbanna K Attalla K, Elbadry M, AAbdeltawab A, et al. Impact of floral sources and processing on the antimicrobial activities of different unifloral honeys. Asian Pac J Trop Dis. 2014;4(3):194-200.

22. Kwakman P H, Zaat SA. Antibacterial components of honey. IUBMB Life. 2012;64(1):48-55.

23. Al-Ani I, Zimmermann S, Reichling J, et al. Antimicrobial activities of European propolis collected from various geographic origins alone and in combination with antibiotics. Medicines. 2018;5(1):2.

24. Elgamily H, Ghallab O, El-Sayed H, et al. Antibacterial potency and fluoride release of a glass ionomer restorative material containing different concentrations of natural and chemical products: An in-vitro comparative study. J Clin Exp Dent. 2018;10(4):e312-e320.

25. Oliveira A, Sousa JC, Silva AC, et al. Chestnut Honey and Bacteriophage Application to Control Pseudomonas aeruginosa and Escherichia coli Biofilms: Evaluation in an ex vivo Wound Model. Front Microbiol. 2017;9:1725

26. Khan SU, Anjum SI, Rahman K, et al. Honey: Single food stuff comprises many drugs. Saudi J Biol Sci. 2018;25(2):320-325.

27. Feás X, Iglesias A, Rodrigues S, et al. Effect of Erica sp. honey against microorganisms of clinical importance: study of the factors underlying this biological activity. Molecules. 2013;18(4):4233-4246.

28. Bucekova M, Buriova M, Pekarik L, et al. Phytochemicals-mediated production of hydrogen peroxide is crucial for high antibacterial activity of honeydew honey. Sci Rep. 2018;13;8(1):9061.

29. Brudzynski K, Lannigan R. Mechanism of Hhoney bacteriostatic action against MRSA and VRE involves hydroxyl radicals generated from honey's hydrogen peroxide. Front Microbiol. 2012;7(3):36.

30. Libonatti C, Soledad V, Marina B. Antibacterial activity of honey: A review of honey around the world. $J$ Microbiology and Antimicrobials. 2014;6(3):51-56. 
31. Ahmed MR, Shaikh MA, Ul Haq SHI, et al. Neuroprotective role of chrysin in attenuating loss of dopaminergic neurons and improving motor, learning and memory functions in rats. Int J Health Sci (Qassim). 2018;12(3):35-43.

32. Molan P C. The antibacterial activity of honey. 1. The nature of the antibacterial activity. Bee World. 1992;73(1):5-28.

33. Rani GN, Budumuru R, Bandaru NR. Antimicrobial activity of honey with special reference to methicillin resistant Staphylococcus aureus (MRSA) and methicillin sensitive Staphylococcus aureus (MSSA). J Clin Diagn Res. 2017;11(8):DC05-DC08.

34. Júnior FA, Balestrin EC, Betoni JE, et al. Propolis: anti-Staphylococcus aureus activity and synergism with antimicrobial drugs. Mem Inst Oswaldo Cruz. 2005;100(5):563-566.

35. Vivek P, Supriya N. A Review on Antimicrobial Activity of honey. International Journal of Trend in Scientific Research and Development (IJTSRD). 2018;2(4).

36. Ishisaka A, Ikushiro $\mathrm{S}$, Takeuchi $\mathrm{M}$, et al. In vivo absorption and metabolism of leptosperin and methyl syringate, abundantly present in manuka honey. Mol Nutr Food Res. 2017;61(9).

37. Afrouzan $\mathrm{H}$, Tahghighi A, Zakeri S, et al. Chemical Composition and Antimicrobial Activities of Iranian Propolis. Iran Biomed J. 2018;22(1):50-65

38. Vega RS, De Mendonça S, Mendes PB, et al. Artepillin C and phenolic compounds responsible for antimicrobial and antioxidant activity of green propolis and Baccharis dracunculifolia DC. J Appl Microbiol. 2017;122(4):911-920.

39. da Cruz Almeida ET, da Silva MCD,Oliveira JMDS, et al. Chemical and microbiological characterization of tinctures and microcapsules loaded with Brazilian red propolis extract. J Pharm Anal. 2017;7(5):280-287.

40. Choi JH, Jang AY, Lin S, et al. Melittin, a honeybee venom-derived antimicrobial peptide, may target methicillin-resistant Staphylococcus aureus. Mol Med Rep. 2015;12(5):6483-6490.

41. Ebbensgaard A, Mordhorst H, Aarestrup FM, et al. The Role of Outer Membrane Proteins and Lipopolysaccharides for the Sensitivity of Escherichia coli to Antimicrobial Peptides. Front Microbiol. 2018;9:2153.

42. Dosler S, Karaaslan E, Alev Gerceker A. Antibacterial and anti-biofilm activities of melittin and colistin, alone and in combination with antibiotics against Gram-negative bacteria. J Chemother. 2016;28(2):95-103.

43. Abd El-Hafeez MM, Abd El-Kader H, Sayed AM, et al. A bacteriologica study on bovine endometritis, with special reference to its treatment with honey infusion. Assiut Medical Journal. 2001;45(89):289-302.

44. Hilary S, Habib H, Souka U, et al. Bioactivity of arid region honey: an in vitro study. BMC Complement Altern Med. 2017;17(1):177.

45. Jóhannesson T, Gudmundsdóttir KB, Eiríksson T, et al. Selenium and GPX activity in blood samples from pregnant and non-pregnant ewes and selenium in hay on scrapie-free, scrapie-prone and scrapie-afflicted farms in Iceland. Icel Agr Sci. 2005;16/17:3-13.

46. Arabmoazzen S, Sarkaki A, Saki G, et al. Antidiabetic effect of honey feeding in noise induced hyperglycemic rat: involvement of oxidative stress. Iran J Basic Med Sci. 2015;18(8):745-751.

47. Stahl W, Sies H. Antioxidant activity of carotenoids. Mol Aspect Med. 2003;24(6):345-351.

48. McCall MR, Frei B. Can antioxidant vitamins materially reduce oxidative damage in humans? Free Rad Biol Med. 1999;26(7-9):1034-1053.

49. Khalil M, Boukraa L. Antioxidant Properties of Honey and Its Role in Preventing Health Disorder. The Open Nutraceuticals Journal. 2010;3:6-16.
50. Vela L, De Lorenzo C, Pérez RA. Antioxidant capacity of Spanish honeys and its correlation with the polyphenolic content and other physicochemical properties. J Sci Food Agric. 2007;87(6):1069-1075.

51. Mani R, Natesan V. Chrysin: Sources, beneficial pharmacological activities, and molecular mechanism of action. Phytochemistry. 2018; 145:187-196.

52. Pérez RA, Iglesias MT, Pueyo E, et al. Amino acid composition and antioxidant capacity of Spanish honeys. J Agric Food Chem. 2007;55(2):360-365

53. Abdulazez MK, Yusoff KM. Honey extracts have 'potent' antiInflammatory, analgesic effect: Identification of polyphenolic antioxidants from honey methanol and ethyl acetate extracts and their anti- inflammatory and antinociceptive activities. The 6th German Apitherapy and Apipuncture Congress held in Passau from March 27th to April 1st, 2008.

54. Sun L, Liao L, Wang B. Potential Antinociceptive Effects of Chinese Propolis and Identification on Its Active Compounds. J Immunol Res. 26;2018:5429543.

55. Choi MJ, Park JS, Park JE, et al. Galangin Suppresses Pro-Inflammatory Gene Expression in Polyinosinic-Polycytidylic Acid-Stimulated Microglial Cells. Biomol Ther (Seoul). 2017;25(6):641-647.

56. Kang MK, Lee EJ, Kim YH, et al. Chrysin Ameliorates Malfunction of Retinoid Visual Cycle through Blocking Activation of AGE-RAGEER Stress in Glucose-Stimulated Retinal Pigment Epithelial Cells and Diabetic Eyes. Nutrients. 2018;10(8). pii: E1046.

57. Escriche I, Kadar M, Juan-Borrás M, et al. Suitability of antioxidant capacity, flavonoids and phenolic acids for floral authentication of honey. Impact of industrial thermal treatment. Food Chem. 2014;142:135-143.

58. Yu XM, Phan T, Patel PN, et al. Chrysin activates Notch1 signaling and suppresses tumour growth of anaplastic thyroid carcinoma in vitro and in vivo. Cancer. 2013;119(4):774-781.

59. Almasaudi SB, Abbas AT, Al-Hindi RR, et al. Manuka Honey Exerts Antioxidant and Anti-Inflammatory Activities That Promote Healing of Acetic Acid-Induced Gastric Ulcer in Rats. Evid Based Complement Alternat Med. 2017;2017:5413917.

60. Sayed SM, Abou El-Ella GA, Wahba NM, et al. Immune defense of rats immunized with fennel honey, propolis, and bee venom against induced Staphylococcal infection. J Med Food. 2009;12(3):569-575.

61. Neveen A EL-Nisr, Abd El Rahman MF, Ghada A Abou El-Ella, et al. Immunomodulatory response of Apitherapy. I- Bioassay of some Apiproducts and their influence on haemo-immunodynamics in rats. Villa Mondragone Roma, Italy: Apimedica and Apiquality 2nd International Fourum 9-12;2008.

62. Tonks AJ, Cooper RA, Jones KP, et al. Honey stimulates inflammatory cytokine production from monocytes. Cytokine. 2003;21(5):242-247.

63. Fischer G, Conceica o FR, Leite FP, et al. Immunomodulation produced by a green propolis extract on humoral and cellular responses of mice immunized with SuHV-1. Vaccine. 2007;25:1250-1256.

64. A1-Waili NS, Lootah S. Safety and effectiveness of repeated intravenous infusion of natural honey on haematological and biochemical investigations in sheep. FASEB J. 2001;15:A136.

65. Muda T, Ismail Z, Abdullah S, et al. The Effects of Honey on Inflammatory Cells in Cigarette Smoke Affected Lungs in Rats: A Preliminary Study. Research J Pharm Tech. 2014;7(12):1382-1386.

66. Cheng N, Wang Y, Cao W. The Protective Effect of Whole Honey and Phenolic Extract on Oxidative DNA Damage in Mice Lymphocytes Using Comet Assay. Plant Foods Hum Nutr. 2017;72(4):388-395.

67. Živković L, Bajić V, Dekanski D, et al. Manuka honey attenuates oxidative damage induced by $\mathrm{H} 2 \mathrm{O} 2$ in human whole blood in vitro. Food Chem Toxicol. 2018;119:61-65. 
68. Rahim M, Ooi FK, Wan Abdul Hamid WZ. Blood immune function parameters in response to combined aerobic dance exercise and honey supplementation in adult women. $J$ Tradit Complement Med. 2016;7(2):165-171.

69. Aduharfeil N, Al-Oran R, Abo-Shehada M. The effects of bee honey on the proliferative activity of human B and T lymphocytes and activity of phagocytes. Food Agric Immunol. 1999;11:169-177.

70. Zahraa AA. The effects of honey on phagocytic activity against Staphylococcus aureus. Journal of Kerbala University. 2011;9(3):335339

71. Sforcin JM. Propolis and the immune system: a review. JEthnopharmacol. 2007;113:1-14.

72. Missima F, Sforcin JM. Green Brazilian propolis action on macrophages and lymphoid organs of chronically stressed mice. Evid Based Complement Alternat Med. 2008;5(1):71-75.

73. El-Asely AM, Abbass AA, Austin B. Honey bee pollen improves growth, immunity and protection of Nile tilapia (Oreochromis niloticus) against infection with Aeromonas hydrophila. Fish Shellfish Immunol. 2014;40(2):500-506.

74. Stuchal LD, Kleinow KM, Stegeman JJ, et al. Demethylation of the pesticidemethoxychlor in liver and intestine from untreated, methoxychlor-treated, and 3-methylcholanthrene-treated channel catfish (Ictalurus punctatus): evi-dence for roles of Cyp1 and Cyp3a family isozymes. Drug Metab Dispos. 2006;34(6):932-938.

75. Neveen A EL Nisr, Eman E El-Sharkawy, MR Abd Ellah, et al. AbdelRahman Ameliorative effect of propolis against methoxychlor induced hepato renal dysfunction. Basic Research Journal of Animal Scienc. 2013;1(1): 7-16

76. El-Sharkawy EE, Kames AO, Sayed SM, et al. The ameliorative effect of propolis against methoxychlor induced ovarian toxicity in rat. Exp Toxicol Pathol. 2014;66(9-10):415-421.

77. Manikkam M, Haque MM, Guerrero-Bosagna C, et al. Pesticide methoxychlor promotes the epigenetic transgenerational inheritance of adult-onset disease through the female germline. PLoS One. 2014;9(7):e102091.

78. Arabameri A, Sameni H, Bandegi A. The effects of propolis extract on ovarian tissue and oxidative stress in rats with maternal separation stress. Int J Reprod Biomed (Yazd). 2017;15(8):509-520.

79. Abdul-Hamid M, Salah M. Intervention of ginger or propolis ameliorates methotrexate - induced ileum toxicity. Toxicol Ind Health. 2016;32(2):313-322.

80. Russo A, Troncoso N, Sanchez F, et al. Propolis protects human spermatozoa from DNA damage caused by benzo[a]pyrene and exogenous reac-tive oxygen species. Life Sci. 2006;78(13):1401-1406.

81. El-Sheikh A, Ibrahim H. The Propolis Effect on Chlorpyrifos Induced Thyroid Toxicity in Male Albino Rats. Journal of Medical toxicology and Forensic medicine. 2017;3:3

82. Samarghandian S, Farkhondeh T, Azimi-Nezhad M. Protective Effects of Chrysin Against Drugs and Toxic Agents. Dose Response. 2017;15(2):1559325817711782.

83. Lee EJ, Kang MK, Kim DY, et al. Chrysin Inhibits Advanced Glycation End Products-Induced Kidney Fibrosis in Renal Mesangial Cells and Diabetic Kidneys. Nutrients. 2018;10(7). pii: E882.

84. Raslan AA, Elbadry S, Darwish WS. Estimation and Human Health Risk Assessment of Organochlorine Pesticides in Raw Milk Marketed in Zagazig City, Egypt. J Toxicol. 2018;2018:3821797.

85. Ozden-Akkaya O,Altunbas K, Yagc1 A. Effects of methoxychlor on IGF-I signaling pathway in rat ovary. Biotech Histochem. 2017;92(3):230-242.
86. Liu S, Li C, Wang Y, et al. In utero methoxychlor exposure increases rat fetal Leydig cell number but inhibits its function. Toxicology. 2016;370:31-40.

87. Babica P, Zurabian R, Kumar E, et al. Methoxychlor and Vinclozolin Induce Rapid Changes in Intercellular and Intracellular Signaling in Liver Progenitor Cells. Toxicol Sci. 2016;153(1):174-185.

88. Bischof I, Köster J, Segner H, et al. Hepatocytes as in vitro test system to investigate metabolite patterns of pesticides in farmed rainbow trout and common carp: Comparison between in vivo and in vitro and across species. Comp Biochem Physiol C Toxicol Pharmacol. 2016;187:62-73.

89. Martyniuk CJ, Spade DJ, Blum JL, et al. Methoxychlor affects multiple hormone signaling pathways in the largemouth bass (Micropterus salmoides) liver. Aquat Toxicol. 2011;101(3-4):483-492.

90. Cheng $\mathrm{HH}, \mathrm{Lu} \mathrm{YC}$, Lu T, et al. Effect of methoxychlor on $\mathrm{Ca}(2+)$ movement and viability in MDCK renal tubular cells. Basic Clin Pharmacol Toxicol. 2012;111(4):224-231.

91. Abdel-Hafeez MM, Ali MM, Abdel-Rahman MF, et al. Antibacterial Activity of Honey for Treatment of Subclinical Bovine Mastitis: Intramammary Infusion as a Tool to Manage Non Responding Antibiotic Cases. 8th Congress Egyptian Society of Cattle Diseases. 2005. p. 147150 .

92. Wahba NM, El Nisr NA, Hamuda SM, et al. Intramammary honey infusion: A new trend in the management of subclinical mastitis. Journal of Animal and Veterinary Advances. 2011;10(20):2740-2744.

93. Ali MA, Saleh AS, Abdul-Hafeez MM, et al. Honey and Medicinal Plants in the Management of Certain Surgical Bovine Clow Affections. Int J Complement Alt Med. 2017;9(3):00091.

94. AhujaA, Cheema R, Narang D, et al. Bacterial Pathogens and Antibiotic Susceptibility Patterns of Cervico-Vaginal Discharges in Cross Bred Repeat Breeding Heifer Cows. Int J Curr Microbiol App Sci. 2017;6(6):1769-1775.

95. Ghanem ME, Tezuka E, Devkota B, et al. Persistence of uterine bacterial infection, and its associations with endometritis and ovarian function in postpartum dairy cows. J Reprod Dev. 2015;61(1):54-60.

96. Azizunnesa A, Joy S, Faruk M. Isolation and Identification of Uterine Microorganisms in Postpartum Dairy cows. Bangladesh J Microbiol. $2011 ; 28(1): 19-23$

97. Ahmadi M, Hosseini A, Gheisari H, et al. Preliminary trial in treatmen of postpartum endometritis with intrauterine application of hyperimmune serum in dairy cows. Asian Pac J Trop Dis. 2014;4(Suppl 1):S360-S365.

98. Singuri C. Therapeutic management of endometritis in graded murrah buffalo (Bubalus bubalis) cows using certain immunomodulars. India: Thesis Sri Venkateswara Veterinary Uni; 2014.

99. Verma S, Choudhary A, Maini S, et al. Evaluation of Efficacy of Herbal Intrauterine Infusion Uterofix Liquid in Treatment of Various Reproductive Disorders in Cows: A Field Study. Pharmacognosy Res. 2016;8(3):173-175.

100. Daetz R, Cunha F, Bittar JH, et al. Clinical response after chitosan microparticle administration and preliminary assessment of efficacy in preventing metritis in lactating dairy cows. J Dairy Sci. 2016;99(11):8946-8955.

101. Dolezel R, Palenik T, Cech S, et al. Bacterial contamination of the uterus in cows with various clinical types of metritis and endometritis and use of hydrogen peroxide for intrauterine treatment. Veterinarni Medicina. 2010;55(10):504-511.

102. Gurunathan S, Choi YJ, Kim JH. Antibacterial Efficacy of Silver Nanoparticles on Endometritis Caused by Prevotella melaninogenica and Arcanobacterum pyogenes in Dairy Cattle. Int J Mol Sci. 2018;19(4). pii: E1210. 
103. Emre B, Korkmaz Ö, Temamoğullari F, et al. Effect of Intrauterine Infusion of Momordica Charantia L. on Oxidative Stress and Pregnancy Rate in Infertile Cows. J Vet Res. 2017;61(4):489-496.

104. Mandhwani R, Bhardwaz A, Kumar S, et al. Insights into bovine endometritis with special reference to phytotherapy. Vet World. 2017;10(12):1529-1532.

105. Sharma P, SrivastavaS, Kumar R and Singh V: Phytotherapy: An Alternative Low Cost Therapeutic Management of Endometritis in Dairy Animals: A Review. Int J Curr Microbiol App Sci. 2018;2319-7706.

106. Genís S, Cerri RLA, Bach À, et al. Pre-calving Intravaginal Administration of Lactic Acid Bacteria Reduces Metritis Prevalence and Regulates Blood Neutrophil Gene Expression After Calving in Dairy Cattle. Front Vet Sci. 2018;5:135.

107. Ferris R. Current understanding of bacterial biofilms and latent infections: A clinical perspective. Rev Bras Reprod Anim Belo Horizonte. 41(1);74-80.

108. Ferris RA, McCue PM, Borlee GI, et al. In Vitro Efficacy of Non antibiotic Treatments on Biofilm Disruption of Gram-Negative Pathogens and an In Vivo Model of Infectious Endometritis Utilizing Isolates from the Equine Uterus. J Clin Microbiol. 2016;54(3):631-639.

109. Zine el Abidne K, Bouabdellah B. Diagnosis and Treatment of Endometritis with Intra-Uterine Infusion of A Solution of Honey $70 \%$ in Mares. J Vet Sci Technol. 2018;9(1):1000499.

110. Zine el Abidne K, Bouabdellah B. Diagnosis and Treatment of Endometritis with Intra-Uterine Infusion of A Solution of Honey 70\% in Mares. J Vet Sci Technol. 2018.

1.

111. Aghamohammadi M, Haine D, Kelton DF, et al. Herd-Level MastitisAssociated Costs on Canadian Dairy Farms. Front Vet Sci. 2018;5:100.

112. Hussein HA, El-Razik K, Gomaa AM, et al. Milk amyloid A as a biomarker for diagnosis of subclinical mastitis in cattle. Vet World. 2018;11(1):34-41.

113. Jeon SJ, Oh M, Yeo WS, et al. Underlying mechanism of antimicrobial activity of chitosan microparticles and implications for the treatment of infectious diseases. PLoS One. 2014;9(3):e92723.

114. Mushtaq S, Shah AM, Shah A, et al. Bovine mastitis: An appraisal of its alternative herbal cure. Microb Pathog. 2018;114:357-361.

115. Mullen KA. Evaluation of Herbal Oils in Various Preparations for Treating Mastitis in Dairy Cattle. Ph. D. thesis submitted to Graduate Faculty of North Carolina State University, Animal and poultry sciences.

116. Alekish MO, Ismail ZB, Awawdeh MS, Effects of intramammary infusion of sage (Salvia officinalis) essential oil on milk somatic cell count, milk composition parameters and selected hematology and serum biochemical parameters in Awassi sheep with subclinical mastitis. Vet World. 2017;10(8):895-900.

117. Abboud M, El Rammouz R, Jammal B, et al. In Vitro and In Vivo Antimicrobial Activity of two Essential Oils Thymus Vulgaris and Lavandula Angustifolia against Bovine Staphylococcus and Streptococcus Mastitis Pathogen. Middle East Journal of Agriculture Research. 2015;4(4);975-983.
118. Maia NL, de Barros M, de Oliveira LL, et al. Moreira MAS: Synergism of Plant Compound With Traditional Antimicrobials Against Streptococcus spp. Isolated From Bovine Mastitis. Front Microbiol. 2018;9:1203.

119. Abdalhamed AM, Zeedan GS, Zeina HA. Isolation and identification of bacteria causing mastitis in small ruminants and their susceptibility to antibiotics, honey, essential oils, and plant extracts. Vet World. 2018;11(3):355-362.

120. Lanctôt S, Fustier P, Taherian AR, et al. Effect of intramammary infusion of chitosan hydrogels at drying-off on bovine mammary gland involution. J Dairy Sci. 2017;100(3):2269-2281.

121. Beecher C, Daly M, Berry DP, et al. Administration of a live culture of Lactococcus lactis DPC 3147 into the bovine mammary gland stimulates the local host immune response, particularly IL-1beta and IL- 8 gene expression. J Dairy Res. 2009;76(3):340-348.

122. Camperio C, Armas F, Biasibetti E, et al. A mouse mastitis model to study the effects of the intramammary infusion of a food-grade Lactococcus lactis strain. PLoS One. 2017;12(9):e0184218.

123. Mignacca SA, Dore S, Spuria L, et al. Intramammary infusion of a live culture of Lactococcus lactis in ewes to treat staphylococcal mastitis. $J$ Med Microbiol. 2017;66(12):1798-1810.

124. Serna-Cock L, Enríquez C, Zoot, et al. Cellular response of the bovine mammary gland after Weissella confusa infusion to control Streptococcus agalactiae. Rev Colomb Cienc Pecu. 2013;26:280-287.

125. Enríquez-Valencia C, Serna-Cock L, Campos-Gaona R. Intramammary infusion of Weissella confusa affects somatic cell counts and milk differential leukocyte count. Ciência Rural, Santa Maria. 2015;45(5):835-841.

126.h t t p s : / / p d f s. s e m a n t i c s c h o l a r . org / 6 d f 9 eee42c4d467ec9774a6e76ab123caa69772e.pdf

127. Bourabah A, Ayad A, Hammoudi SM, et al. Antimicrobial activity of Algerian honey on subclinical mastitis pathogens isolated from goat's milk. Veterinary World. 2014;7(4):248-252.

128. Bačić C, Macesic N, Radin L, et al. Intramammary propolis formulation for subclinical mastitis prevention and treatment in dairy cows. J Dairy Vet Anim Res. 2016;3(5):159.

129. Kumar N, Manimaran A, Kumaresan A, et al. Mastitis effects on reproductive performance in dairy cattle: a review. Trop Anim Health Prod. 2017;49(4):663-673.

130. Paydar S, Ziaeian B, Dehghanian A, et al. A Comparison of the Effects of Topical Prolavacid Solution (a Polyhexamethylene Biguanide-Based Wound Cleanser) and Medihoney Ointment in a Rat Model of Cutaneous Wound. Adv Wound Care (New Rochelle). 2017;6(12):407-412.

131. Chamani G, Zarei MR, Mehrabani M, et al. Evaluation of Honey as a Topical Therapy for Intraoral Wound Healing in Rats. Wounds. 2017;29(3):80-86

132. Javadi SMR, Hashemi M, Mohammadi Y, et al. Synergistic effect of honey and Nigella sativa on wound healing in rats. Acta Cir Bras. 2018;33(6):518-523.

133. Molan P, Rhodes T. Honey: A Biologic Wound Dressing. Wounds. 2015;27(6):141-151 